UDC 339.138:159.943:7.06

DOI: 10.18523/2519-4739.2021.6.1.122-129

\author{
N. Chala, K. Pichyk, O. Voropai
}

\title{
NEUROMARKETING RESEARCH ON INDIVIDUAL RESPONSES TO ARTWORK: IMPLICATIONS FOR GALLERIES
}

This paper reports the results of neuromarketing research for artworks. It was conducted among young people, students of non-art specialties, for nine different widely known art pieces with the help of eyetracking and emotional scanning equipment.

The aim of the experiment is to determine (1) whether viewers concentrate more on the representational art compared to abstracts art, (2) whether any correlation between the viewing time and the evoked emotions exists, and (3) whether there is any difference between the monitored emotions and those people articulate (in other words, to what extend artwork viewers tell the truth).

The result demonstrates a slightly higher preference in looking at the representational paintings. But we do not notice any correlation between the subjective liking of the painting and the time spent looking at it. An essential difference is recorded for the emotions fixed technically and those reported by the viewers.

The paper also suggests several implications for gallery marketing.

Keywords: eye-tracking, emotions scanning, neuromarketing, galleries marketing, artwork.

\section{JEL classification: M31, Z11}

Introduction and research problem. The art market of every country is the hallmark of its professional cultural development. According to various estimates, the world cultural value turnover is from 120 bln to 1 trillion US dollars. World art market sales demonstrated growth during the last several years. It reached 67.4 bln dollars in 2018 with a $6 \%$ growth compared to the previous year. The global art and antique market in 2019 was estimated by Art Basel experts at 64.1 bln dollars (Art Basel, 2020). However, the total lockdown has revealed problems in this area. In the first six months of 2020, compared to the same period in 2019, sales fell by an average of $36 \%$ (Art Basel, 2020). National art galleries were forced to cease their activities altogether and did not see visitors for six months. But despite the COVID-19 pandemic, $92 \%$ of the collectors stayed active on the market during 2020, with $76 \%$ of them having spent more than $\$ 50000$ (Art Basel, 2020). The Ukrainian art market is much smaller in size. According to various estimates, there are up to 150 art galleries in Ukraine. In 2016, the State Statistics Committee reported 31 art museums and 37 visual art museums in Ukraine (State Statistics Committee of Ukraine, 2017).

Indirectly, the success of an art gallery can be assessed by the number of visitors. They can be divided into two groups - (1) art professionals and real art connoisseurs who are regular gallery visitors, and (2) non-professional consumers who do not attend art exhibitions regularly. Art exhibitions should attract the latter category, awaken their emotions to ensure the steady growth of visitors. This category of naïve observers was the subject of the neuromarketing study described in the article.

According to the State Statistics Committee, in $20161.747 \mathrm{mln}$ people visited visual art museums, and $0.958 \mathrm{mln}$ people visited other art galleries in Ukraine (State Statistics Committee of Ukraine, 2017). There is no official sales data available for the Ukrainian art market. But the name of the most expensive modern Ukrainian artist A. Kryvolap is known globally. Twice in 2011, his paintings set the world price records for modern Ukrainian art. His painting "Step" was sold at the Phillips de Pury \& Co auction in New York for $\$ 98,500$, and the work "Horse Night" at the Phillips de Pury \& Co contemporary art auction in London for $\$ 124,400$ (Artslooker, 2018).

We can divide all artworks into the following categories: national heritage, interior works, and investment instruments. The works from the first group are stored in national art galleries. They belong to the cultural heritage, have a high cultural value, and are very rarely sold at auctions. Interior works are artworks that are characterized by their visual qualities. Artworks from the third group have cultural significance and are in demand in the 
organized art market. Marketing activities and the target audience of the art gallery depend on the type of artwork it displays. This research is valuable for all art galleries, regardless of specialization, as each of them competes for visitors' attention and emotions.

In the current research, we attempt to help Ukrainian galleries and artists understand their customers. Human perception of the visual art objects and the accompanying cognitive process are the focus of this study. We are aimed at determining how neuromarketing tools can be used in the art galleries market to increase its cultural and commercial potential assuming that neuromarketing is able, to a large extent, to explain how a work of art is perceived and what level of aesthetic satisfaction it brings.

We use the collection of 9 paintings of different styles to explore viewers' gazing patterns, fixed and expressed emotions to confirm the following hypotheses: (1) viewers are more concentrated on the representational art, (2) viewers look longer at the works that impress them more, (3) and they can clearly articulate what emotions the artworks evoke in viewers.

The contributions of this research are as follows:

- We conduct an eye-tracking observation to quantify what paintings hold more attention

- We compare those data with impressions reported during the interview, to check whether the correlation between appeal and attention exists

- We use computer vision technology to determine the emotions, images evoke

- We then juxtapose those data with emotions, reported during the interviews

- We suggest steps be taken by galleries to hold viewers' attention and increase their satisfaction.

Recent publications analysis. Our research is close in problems to Heindenreich S., and Turano K. (2003), who were the first researchers to check the peculiarities of museum visitors' visual attention and emotions. Their research was based on the data from 4 naïve viewers looking at 14 artworks. Further research papers by Sartori et al. (2015), Goller J. et al. (2019) and Mitrovic A. et al. (2020) also concentrated on visual attention and emotions. Their aim was to investigate at what level the subjective visual appeal effects the time viewers spend in front of the artwork (fixation duration). The number of respondents and artworks under analysis have gradually increased. Like most of the recent research projects of this kind, ours was also conducted in the lab and explored the behavior of 31 participants (that corresponds with the general practice). Uusitalo L. et al. (2012) investigates viewers' emotions as the factor, influencing their preferences toward the artworks.

Unsolved parts of the problem. It is worth pointing out that the usual neuromarketing research involves a small number of people. Therefore, the additional verification of their conclusions is usually needed. The results provided in our paper are important to confirm the general reliability of this type of research. We use previously unused and not widely known works of art to ensure respondents are unbiased by their previous reflections on the paintings, their context, and knowledge, but rather are reflecting on the style of art. We also carry out the analysis of Ukrainian laypersons that were not previously included in this type of research study.

Research goal and questions. The basic idea of our research was to investigate how naïve observers perceive artworks of different styles and what emotions are evoked during the process. The results were then supposed to be used in gallery management to improve visitors' experience. We have chosen 9 iconic artworks to be demonstrated on the screen in the laboratory. They covered all the main styles from Renaissance to Abstract art (Table 1). These are the works of famous artists. But we have taken the paintings not well-known among the wide audience to offer a fresh experience to the viewers and to track their spontaneous emotions.

The observation involved 31 laypersons ( 9 male, 22 female). The age range was 20-22 years. All the participants were students with good general

\section{Table 1. The list of tested artworks}

\begin{tabular}{|l|l|l|}
\hline \multicolumn{1}{|c|}{ Painter } & \multicolumn{1}{c|}{ Artwork } & \multicolumn{1}{c|}{ Style } \\
\hline Albrecht Dürer & Adam and Eve, 1507 & Renaissance \\
\hline Giuseppe Arcimboldo & Water, 1566 & Mannerism \\
\hline Sir Peter Paul Rubens & The Massacre of the Innocents, 1611-1612 & Baroque \\
\hline Francisco Goya & Saturn Devouring His Son, 1819-1823 & Romanticism \\
\hline Pierre-Auguste Renoir & Portrait of Jeanne Samary, 1877 & Impressionism \\
\hline Pavel Filonov & The Formula of Spring, 1928-1929 & Avant-garde \\
\hline El Lissitzky & Untitled, 1920 (Geometric abstraction) & Avant-garde \\
\hline Joan Miró & Ciphers and Constellations in Love with a Woman, 1941 & Surrealism \\
\hline Mark Rothko & No 1 (Royal Red and Blue), 1954 & Abstract art \\
\hline
\end{tabular}


education but without special knowledge in art or art history. They were chosen by the snowball sampling method (Goodman, 1961) where the pool of the initial participants consisted of 5 students of the Faculty of Economics at the National University of Kyiv-Mohyla Academy (Kyiv, Ukraine). All the viewers were exposed to the same paintings, using eye-tracking and emotion tracking technology.

The testing process covered three main aspects eye-tracking, emotion tracking, and self-report measurement.

Eye-tracking and emotional measurement were conducted using the NeuroLab hardware and the software produced by CoolTool.

The operator who calibrated equipment and provided technical support was also present during the whole experiment. The observations were held in a separate room. Each participant spent

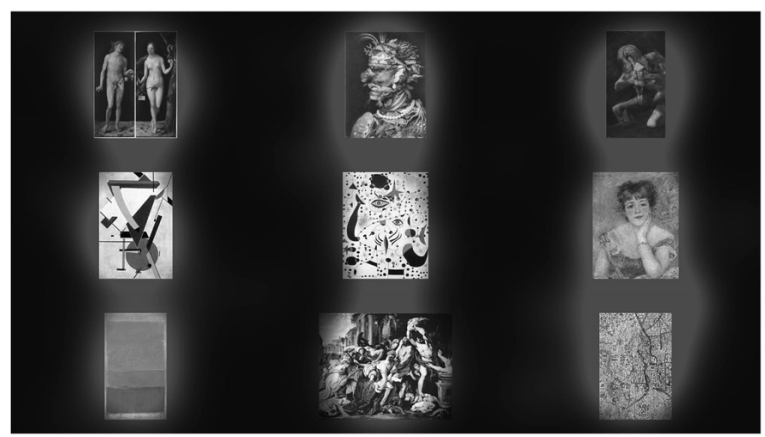

$a$
Question 2. Please, have a look at the paintings again and name three of them that impressed you the most.

Question 9. What feelings did this painting evoke in you? (A closed question with 8 possible variants, any number of which can be chosen): sadness, delight (enjoyment), skepticism (contempt), surprise, negativism (anger), disgust, fear, or neutrality.

Main findings. Eye-tracking allowed us to determine how people look at the paintings, what parts they pay their attention to, and for how long.

Hypothesis 1 (The Plot and The Gaze): Viewers pay more attention to the artworks, depicting people compared to abstract figures.

Figure 1 depicts the areas of respondents' attention when all the 9 paintings are shown simultaneously (we call this a "shelf-mode").

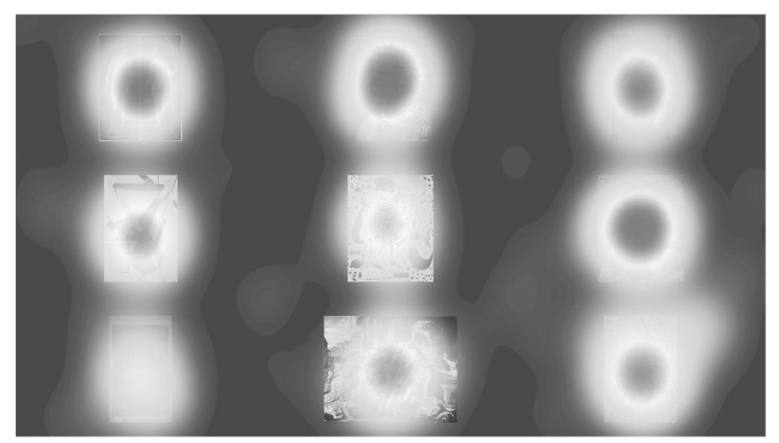

$b$

Fig. 1. Respondents' attention in the "shelf-mode": $a$ - gaze plot; $b$ - heat map

* Painters left to right, top to bottom: Albrecht Dürer, Giuseppe Arcimboldo, Francisco Goya, El Lissitzky, Joan Miró, Sir Peter Paul Rubens, Mark Rothko, Pierre-Auguste Renoir, Pavel Filonov.

approximately 20-25 minutes on both parts of the research - the technological tracking and the interview. Before starting, the researcher made sure the participant felt comfortable wearing the NeuroLab headset and the equipment was ready for recording. After that 9 paintings were displayed randomly on the laptop screen to each participant. Each painting was demonstrated for about 5 seconds. In the end, all nine artworks were shown on one screen and the self-reporting part of the experiment followed. The gaze data and the emotions data were recorded for further analyses.

The self-reporting survey was conducted in the form of a structured face-to-face interview and consisted of 14 questions ${ }^{1}$. The further discussion will be based on the answers to the following questions (translated from Ukrainian):

\footnotetext{
1 Not all the questions are covered in this paper. Some of them were used to assess the associations evoked by the paintings and the judgments of the viewers and will be analyzed separately. All the questions are available upon request.
}

The gaze plot (displayed in Fig. 1a) and the heat map (displayed in Fig. 1b) give us a general understanding that artworks, depicting people, faces, or anything resembling a living being attract and hold more attention than purely geometrical abstract artworks. Each painting in this display mode was determined as a separate area of interest (AOI). The average fixation count for 5 artworks with people (Dürer, Arcimboldo, Goya, Rubens, and Renoir) accounted for 59.8 fixations per AOI, while the same parameter for the rest of the paintings (Lissitzky, Miró, Rothko, Filonov) was 4 points less -55.25 . Fixation duration data follows the same rule: respondents looked at the artworks depicting people about $50 \mathrm{~ms}$ longer on average than on the abstract artworks $(0.65 \mathrm{sec}$. versus $0.6 \mathrm{sec}$.) These numbers are consistent and trustful, as the previous research works revealed that the semantic meaning and the structural composition of the artwork can be assessed even at a short glance of $100 \mathrm{~ms}$ (Locher et al., 2007). 
Hypothesis 2 (The Subjective Liking and The Gaze): People look longer at the works that impressed them more.

Figure 2 reports the answers given by respondents when asked about the artworks they were impressed by the most (Question 2).

Comparing the gaze fixation data (Fig. 1b) with the appeal data (Fig. 3) we cannot make a conclusion about a strong correlation between the attention level and the level of appeal. The works by Dürer and Miro were one of the most eye-catching
(67 and 75 fixations respectively when viewed in the "shelf mode"), but they did not greatly impress the viewers according to their reported emotions. On the other hand, Renoir and Goya were less looked at (47 and 46 fixations respectively during the "shelf mode" demonstration) than the abstract painters Filonov and Lissitzky (55 and 56 fixations respectively), but respondents were more impressed by the works of the former. Goya's "Saturn Devouring His Son" impressed the viewers twice as much as the untitled geometric abstraction by Lissitzky (see Fig. 3).

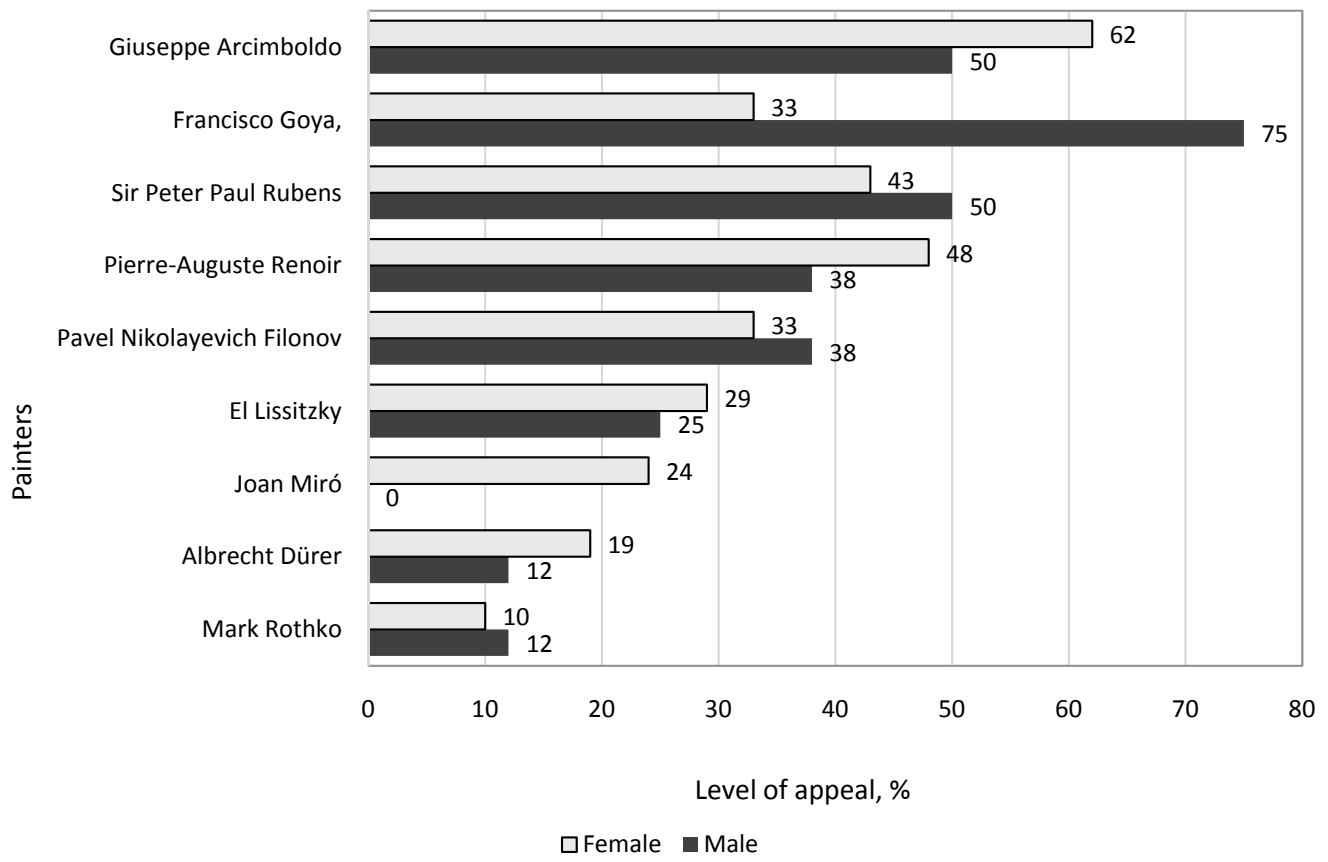

Fig. 2. Which paintings impressed the viewers the most

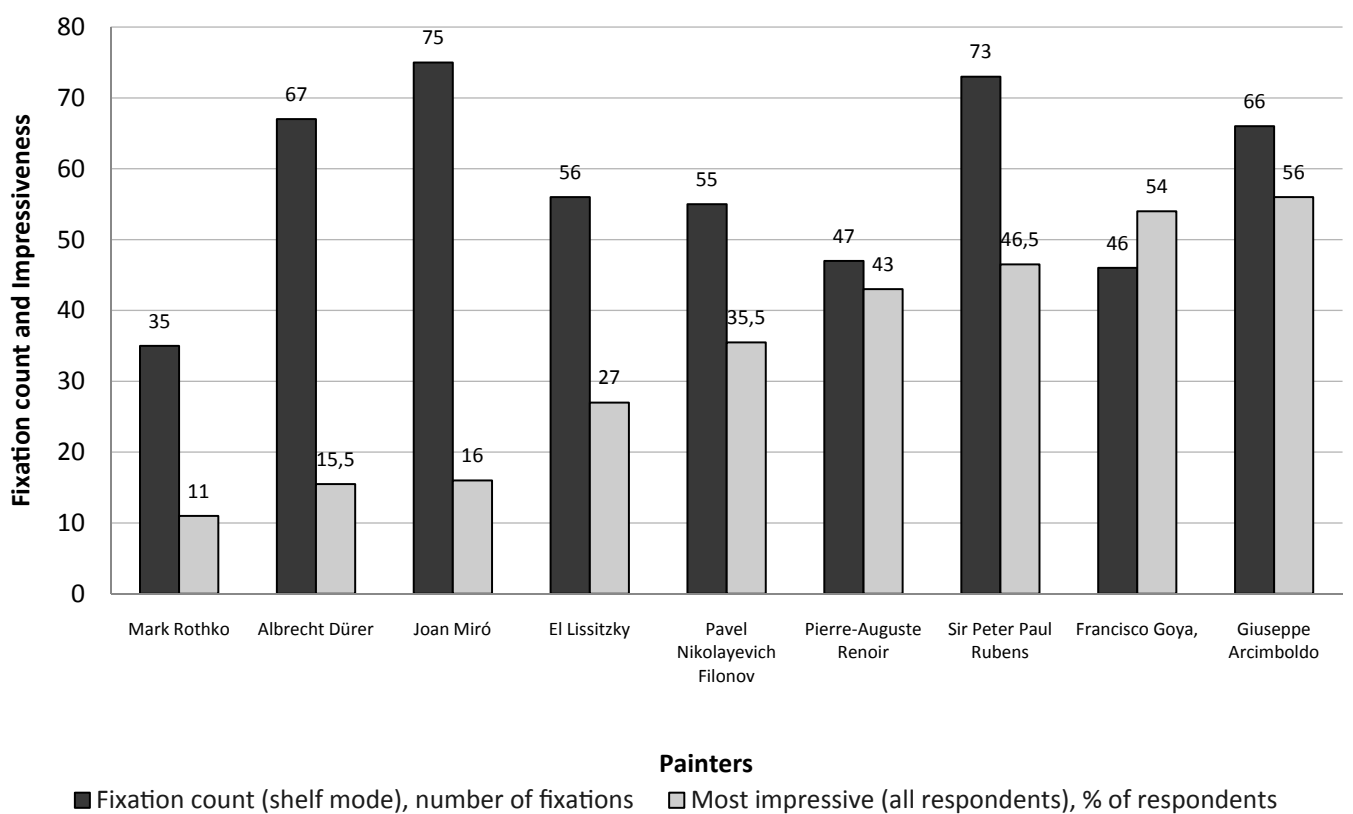

Fig. 3. The level of attention vs the level of artwork appeal 


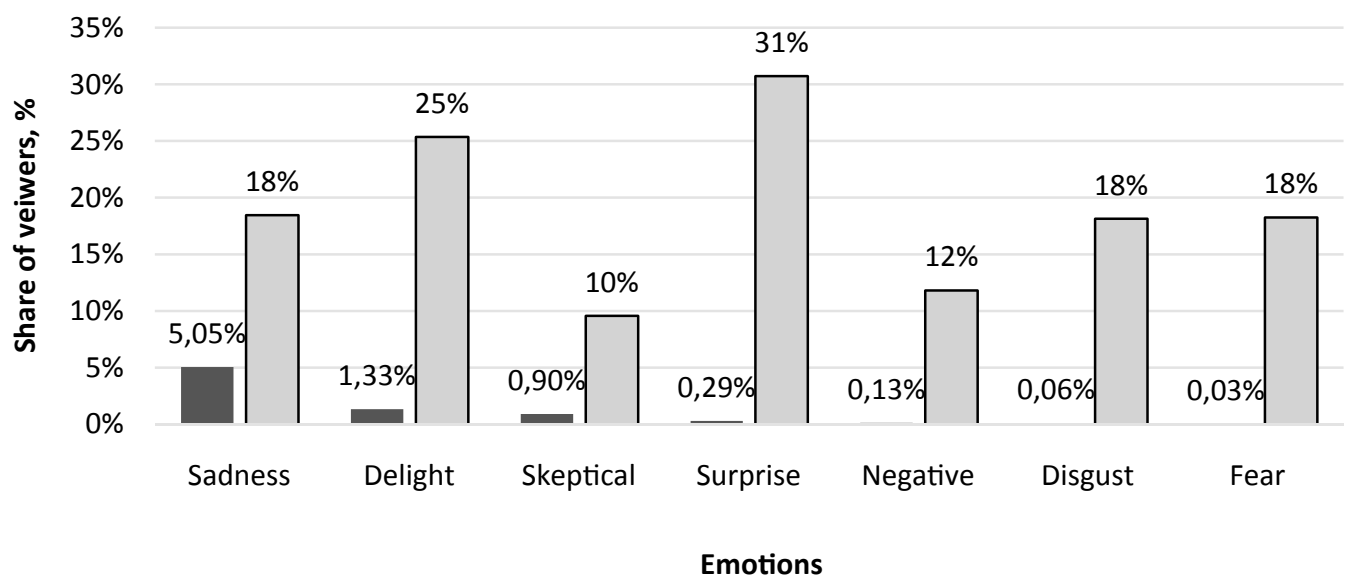

- Average emotions recorded by the NEUROLAB program

$\square$ Average emotions recorded by respondents during the survey

Fig. 4. Comparison of the average emotions fixed by Neurolab and described by the respondents

Hypothesis 3 (Emotions: People VS Equipment): People cannot clearly articulate the emotions the artworks evoke in them.

We used Neurolab EEG hardware and the Neurolab software to determine emotions evoked by the artworks. Neurolab's emotion measurement solution is based on the theory of "universal emotions", introduced by Paul Eckman (2007) and includes seven basic emotions: sadness, delight (enjoyment), skepticism (contempt), surprise, negativism (anger), disgust, and fear. The program also traces the neutral attitude. The average levels of six basic emotions for all 9 artworks recorded by Neurolab and described by people during the questionnaire stage are shown in Figure 4. We aggregate data about the emotions fixed for every viewer and every artwork. Out of the seven basic emotions, four were recognized by the program as the most expressed: sadness, delight, skepticism, and surprise. Anger, disgust, and fear were the least demonstrated emotions.

We then juxtaposed the technically extracted data with the viewers' words. During our interviews, we asked questions to learn about associations, general appeal, and emotions that could be evoked by the artworks. We used answers given to Question 9 (What feelings did this painting evoke in you?) to compare them with the emotions fixed in Neurolab.

The self-reported emotions spectrum is much wider than that recognized by Neurolab (Fig. 4). Not only are more emotions reported by people to be evoked by the artworks, but also the level of those emotions is much higher. While the Neurolab equipment fixated a neutral attitude in most cases.
The distribution of emotions for every painting is also worth attention. ${ }^{2}$ People reported high levels of fear and disgust for Archimboldo's and Goya's masterpieces, while the equipment hardly traced them at all. On the contrary, the self-reported level of sadness was much lower, while this emotion was the most recognized by Neurolab. Sadness and skepticism were noticed by Neurolab as a form of reflection for every artwork in question. But the viewers themselves deny feeling such emotions for some of the paintings. Thus, sadness is not reported to be felt when watching the abstract works by Miro and Rothko. The respondents also believe that half of the paintings do not evoke skepticism, namely Lissitzky, Miro, Renoir, Rubens, and Filonov.

Conclusions and further research proposals. To outline the findings of our research, we would like to emphasize three main points.

Firstly, the current research contributed to the prior works of Uusitalo et al. (2012) and Heidenreich and Turano (2003), comparing different gazing patterns for representational and abstract artworks. Our results show that viewers keep their eyes longer and more often at the artworks depicting living beings, contrary to the abstract paintings. But the limited demonstration time should be taken into account and the results may differ if the display time increases. Schulz and Hayn-Leichsenring (2017), analyzing the viewers' perception of the attractiveness of the depicted person and the artistic beauty of the whole image, concluded that these two values are driven by different processing types: the former is driven mostly by perceptual processes (Kahneman's

2 This publication format does not allow us to provide detailed graphs for each painting, but all the data is available directly from the authors upon request. 
System 1 (Kahneman, 2011)), while the later needs cognitive processing (System 2). The artistic beauty of the artwork had higher ratings in the case of the long-term presentation (3000 ms) and was concluded to be cognitively modulated to some extent. Therefore, we may suggest that in the case of abstract art people need more time to cognitively reflect on the semantic meaning and the aesthetic beauty of the painting. The longer we expose the abstract artwork to the viewers, the more meaning they will be able to notice and the more attention they will pay to the corresponding painting. The data for Miro's surrealistic "Ciphers and Constellations in Love with a Woman" goes in line with this assumption. When displayed on the shelf, the fixation duration for it was the longest $-780 \mathrm{~ms}$. The viewers also fixed their gaze on it for the largest number of times -75 . This abstract painting contains some biological elements (two eyes in the center of the composition) which may be a starting point for comprehending, further cognitive processing, and as a result - longer attention retention.

Secondly, we could not prove any relationship between emotional feedback and the gazing pattern. Similar results were reported by Heidenreich S. and Turano K. (2003). In the museum surrounding they also could not prove any correlation existed between the fixation duration and the emotions aroused. It may be due to the small number of artworks (14 pieces) and respondents (4 laypersons) analyzed. Though we engaged more respondents (31 naive viewers), the number of artworks in question was even lower ( 9 pieces) and it could influence the results. The display time could also influence the viewers' behavior and prevent them from demonstrating the same attention distribution as they would have demonstrated in real life. People generally need more time to start reflecting (Leder et al., 2006) and their viewing activity was limited in the experiment to only $500 \mathrm{~ms}$.

Thirdly, the comparison of the technically recognized and the self-reported emotions demonstrate that the practical value of the classical users' questionnaires for galleries is controversial. On the one hand, people tend to embellish the truth or to tell things they believe they are supposed to tell. They may also not correctly recognize the emotions felt due to the different levels of emotional intelligence. Therefore, the result of the polls and interviews may be inaccurate and lead to inefficient decisions. In this case, the neuromarketing tools can either be used as self-sufficient research instruments or as a way to double-check a research hypothesis. On the other hand, Neurolab recognizes only a small number of basic emotions while current research works report a much wider spectrum where not all the emotions can be distinctly recognized from one another. Cowen and Keltner (2017) write about 27 categories of emotions, changing in a gradient-like style. Therefore, interviews may be more useful if a less aggregate and a more detailed reflection about artworks is needed.

When interpreting the emotion tracking results, we should also take into consideration the form of the question asked. In our case, the answer was limited to a list of seven possible emotions (the same as tracked by Neurolab). Therefore, the answer could be biased as the possible alternatives were suggested to the respondent.

It should also be pointed out that there were three emotions almost not recognized by the technical emotion tracking - anger (negative), disgust, and fear. As all the demonstrated paintings were wellknown works by famous artists highly valued by the collectors as well as by the general public, we can suppose that these are the emotions, artists should avoid evoking for their artworks to become famous and to enrich the national heritage in the future.

The neuromarketing experiments, based on eyetracking and emotional measurement, can be beneficial for gallery management as they give additional understanding of visitors' behavior. Below is the list of the recommendations that galleries can implement. The list is based on the results of our research and the previous related research papers we analyzed.

- Gathering eye-tracking feedback about visual attention instead of questionnaires/polls

Artists often report a lack of feedback from the viewers about their works, the attitude toward composition, the most liked elements, emotions evoked. Normally such feedback is gathered in a form of oral or written questionnaires and often ignored by gallery visitors. Besides, a great part of the cognitive processes during an artwork exposure is unconscious and can hardly be reported by visitors. Therefore eye-tracking techniques could help in gathering such feedback either during gallery visits or as a part of a specially designed research. Previous research studies did not find any evidence that eye-tracking changed the emotional experience or the attitudes of the viewers (Pelowski et al., 2018; Mitschke et al., 2017). This could also become a part of the online visiting experience when a digital gallery tour is complemented with the eye-tracking research regarding visual response to artworks. Bauman B. et al. (2018) suggested using a separate online platform for these purposes, where artists upload their works and viewers are giving their visual feedback via the ordinary computer webcam. But similar software could also be integrated with the galleries' websites. 
- Context formation and consumer education before visits

The early works of Bourdieu (1984) demonstrate a positive correlation between the level of art competency and the preference toward the paintings. These findings were later supported by Bauer D. and Schwan S. (2018). Their eye-tracking experiment with two separate groups of people - students of art history and those with no special art background questions the popular hypothesis in aesthetic psychology that experts focus on style, while laypersons concentrate on the content. Just on the contrary, art history students demonstrated deeper cognitive involvement, searched for meaning-making content, and gave broader interpretations.

The same is true when the artist or at least the style is familiar to the layperson. That is why research papers prove higher preferences toward representational art against the more abstract contemporary art among laypersons (Ahola \& Uusitalo, 2008). Our study also confirms that people demonstrated higher preferences for the artworks when they knew the context. Therefore, we can suggest that galleries organize educational promotional campaigns. Even small portions of information about the artist, paintings, and the context will increase visitors' art competency and will result in a higher level of preferences. Uusitalo et al. (2012) report a slight increase of preferences for abstract paintings based even on such an approximate measure of consumers' art expertise as the number of art gallery visits per year regardless of the quality of such visits. We can assume that giving a short 1-minute in-person introduction at the beginning of the visit could improve the tendency and would lead to even higher levels of preference for any artworks, especially the contemporary abstract ones. Information displays and artwork titles also contribute to the general liking and emotional response of the visitors. The study by Bubić A., Sušac A., \& Palmović M. (2017) confirms that liking, understanding, and emotional impact is higher for painting with titles compared to those with no titles.

\section{- Emotional tags (labels)}

Neuromarketing research may result in labeling artworks depending on the emotions they evoke. Based on the reactions, common for a group of people, a whole exhibition may be planned as "joyful" or "melancholic" as well as the separate exhibition rooms within one project can be planned. Such tagging for movies was described by Y. Ding, X. Hu, Z. Xia, Y.-J. Liu, and D. Zhang (2018) and S. Koelstra and I. Patras (2013) based on the results of EEG signals and facial expressions. Tarnowski et al. (2020) report obtaining $80 \%$ accuracy when recognizing three classes of emotions (high arousal and high valence; high arousal and low valence; low arousal and moderate valence) with eye-tracking tools. As a result, we may conclude that such techniques can be beneficially used in practice.

\section{- Exhibition layout}

Our shelf-view imitated the way people see artworks when entering the exhibition room for the first time. Based on the gaze fixation results, we can conclude that for visitors to notice and reflect on the abstract painting it should not be displayed next to the artworks featuring any people, their faces, or anything resembling them.

The fast-changing business and cultural environment is forcing galleries to look for alternative marketing and development plans. Such cross-disciplinary research experiments combining psychology, consumer behavior, and marketing allow scientists and marketing specialists to find out-of-the-box decisions. Neuromarketing tools, described in our research, support galleries with the technically extracted, unbiased data for more reasoned decisions. Further work may be done in analyzing the economic benefit of neuromarketing research in the art market.

\section{References}

Ahola, E.-K., \& Uusitalo, L. (2008). Can We Segment Art Museum Visitors? A Study of Segmentation Based on Consumer Motives and Preferences. In Museum and Visual Art Markets (pp. 157-168). Helsinki: Helsinki School of Economics. http://epub.lib.aalto.fi/pdf/hseother/b96.pdf

Art Basel. (2020). The art market 2020. Highlights. Art Basel Report. https://theartmarket.foleon.com/2020/artbasel/the-art-market2020-highlights/

Artslooker. (2018). 10 naidorozhchykh kartyn Anatoliia Kryvolapa, yaki bulo prodano na auktsionakh $[10$ most expensive A. Kryvolap's paintings sold at the auctions]. https://artslooker com/10-naydorozhchikh-kartin-anatoliya-krivola-yaki-buloprodano-na-auctionakh/ [in Ukrainian].

Bauer, D., \& Schwan, S. (2018). Expertise influences meaning-making with renaissance portraits: Evidence from gaze and thinking-aloud Psychology of Aesthetics, Creativity, and the Arts, 12(2), 193-204.
Bauman, B., Gunhouse, R., Jones, A., Silva, W., Sharar, S., Rajanna, V. \& Hammond, T. (2018). VisualEYEze: A Web-based Solution for Receiving Feedback on Artworks Through Eye-Tracking. IUI Workshops. http://ceur-ws.org/Vol-2068/wii4.pdf

Bourdieu, P. (1984). Distinction: A Social Critique of the Judgement of Taste. Cambridge, MA: Harvard University Press.

Bubić, A., Sušac, A., \& Palmović, M. (2017). Observing individuals viewing art: The effects of titles on viewers' eye-movement profiles. Empirical Studies of the Arts, 35(2), 194-213.

Cowen, A., \& Keltner, D. (2017). Self-report captures 27 distinct categories of emotion bridged by continuous gradients. PNAS, 114(38), 7900-7909.

Ding, Y., Hu, X., Xia, Z., Liu, Y.-J., \& Zhang, D. (2018). Inter-brain EEG feature extraction and analysis for continuous implicit emotion tagging during video watching. IEEE Transactions on Affective Computing, 1. 
Eckman, P. (2007). Emotions revealed: Recognizing faces and feelings to improve communication and emotional life (2nd ed.) NY: Henry Holt and Company LLC.

Goller, J., Mitrovic, A., \& Leder, H. (2019). Effects of liking on visual attention in faces and paintings. Acta Psychologica, 197, 115-123.

Goodman, L. (1961). Snowball sampling. Annals of Mathematical Statistics, 32(1), 148-170.

Heidenreich, S., \& Turano, K. (2003). What predicts where one will look when viewing artwork? Journal of Vision, 3(9).

Kahneman, D. (2011). Thinking, fast and slow. New York: Farrar, Straus and Giroux

Koelstra, S., \& Patras, I. (2013). Fusion of facial expressions and EEG for implicit affective tagging. Image and Vision Computing, 31(2), 164-174.

Leder, H., Carbon, C.-C., \& Ripsas, A.-L. (2006). Entitling Art: Influence of Title Information on Understanding and Appreciation of Paintings. Acta Psychologica, 121, 176-198.

Locher, P., Krupinski, E., Mello-Thoms, C., \& Nodine, C. (2007). Visual interest in pictorial art during an aesthetic experience. Spatial Vission, 21, 55-77.

Mitrovic, A., Hegelmaier, L., Leder, H., \& Pelowski, M. (2020). Does beauty capture the eye, even if it's not (overtly) adaptive? A comparative eye-tracking study of spontaneous attention and visual preference with VAST abstract art. Acta Psychologica, 209.
Mitschke, V., Goller, J., \& Leder, H. (2017). Exploring everyday encounters with street art using a multimethod design. Psychology of Aesthetics Creativity and the Arts, 11(3), 276-283.

Pelowski, M., Leder, H., Mitschke, V., Specker, E., Gerger, G., Tinio, P., \& Husslein-Arco, A. (2018). Capturing Aesthetic Experiences With Installation Art: An Empirical Assessment of Emotion, Evaluations, and Mobile Eye Tracking in Olafur Eliasson's “Baroque, Baroque!”. Frontiers in Psychology, 9.

Sartori, A., Yanulevskaya, V., Akdag Salah, A., Uijlings, J., Bruni, E., \& Sebe, N. (2015). Affective Analysis of Professional and Amateur Abstract Paintings Using Statistical Analysis and Art Theory. ACM Transactions on Interactive Intelligent Systems, 5, 1-27.

Schulz, K., \& Hayn-Leichsenring, G. (2017). Face Attractiveness versus Artistic Beauty in Art Portraits: A Behavioral Study. Frontiers in Psychology, 8.

State Statistics Committee of Ukraine. (2017, April 11). Merezha ta diialnist muzeiv u 2016 rotsi [Network and activities of museums in 2016]. http://www.ukrstat.gov.ua/express/expr2017/expres u.html

Tarnowski, P., Kołodziej, M., Majkowski, A., \& Rak, R. (2020). Eye-Tracking Analysis for Emotion Recognition. Computational Intelligence and Neuroscience, 1-13.

Uusitalo, L., Simola, J., \& Kuisma, J. (2012). Consumer Perception of Abstract and Representational Visual Art. International Journal of Arts Management, 15(1), 30-41.

Чала Н. Д., Пічик К. В., Воропай О. К.

\section{НЕЙРОМАРКЕТИНГ ЯК ІНСТРУМЕНТ ВИВЧЕННЯ РЕАКЦЇ ГЛЯДАЧІВ НА ТВОРИ МИСТЕЦТВА: ВИСНОВКИ ДЛЯ КАРТИННИХ ГАЛЕРЕЙ}

Нейромаркетинг як інструмент дослідження поведінки споживачів активно використовується для аналізу споживчої реакції на візуальні маркетингові стимули (друковану та відеорекламу, зображення на упаковці тощо). Це дослідження спрямоване на з'ясування можливостей інструментів нейромаркетингу в ситуації, коли зображення $є$ не допоміжним елементом комплексу маркетингу, а основним товаром. Ай-трекінг і відстеження емоцій використано для аналізу поведінки споживачів під час перегляду ними творів візуального мистецтва. На підставі отриманих результатів сформульовано маркетингові рекомендації для менеджерів та власників картинних галерей.

У роботі подано результати спостереження за 31 учасником - непрофесійними поціновувачами творів мистецтва, яким було представлено 9 маловідомих картин визнаних світом художників. Характер уваги, тривалість погляду, тип та рівень емоцій учасників експерименту фіксували за допомогою ай-трекінгових окулярів.

Мета дослідження - визначити, (1) чи довше глядачі дивляться на реалістичні картини порівняно 3 абстрактними, (2) чи пов'язаний час перегляду картини з емоціями, які вона викликає, і (3) чи $\epsilon$ різниця між емоціями, зафіксованими технічними засобами, і тими, які озвучують самі глядачі. Результати вказують на незначний рівень преференцій (тривалості перегляду) реалістичних сюжетів. Нам не вдалося зафіксувати кореляцію між часом перегляду та рівнем уподобань глядачів. Водночас виявлено суттєву різницю між характером та рівнем емоцій, зафіксованих апаратно та висловлених респондентами під час інтерв'ю.

На основі отриманих результатів зроблено висновок про те, що інструменти нейромаркетингу можуть забезпечити галереям об'єктивні та неупереджені дані для обгрунтованого ухвалення управлінських рішень. Утім, потрібні подальші дослідження для визначення економічної доцільності нейромаркетингових досліджень на ринку творів мистецтва.

Ключові слова: ай-трекінг, спостереження за емоціями, нейромаркетинг, маркетинг галерей, твори мистецтва.

Матеріал надійшов 28.04.2021

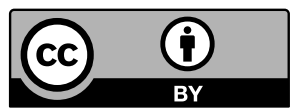

Creative Commons Attribution 4.0 International License (CC BY 4.0) 